\title{
GC-MS Evaluation, Antioxidant Content, and Cytotoxic Activity of Propolis Extract from Peninsular Malaysian Stingless Bees, Tetrigona Apicalis
}

\author{
Wan Ahmad Syazani Mohamed $\left(\mathbb{D},{ }^{1}\right.$ Noor Zafirah Ismail ${ }^{1},{ }^{1}$ Eshaifol Azam Omar (D), \\ Nozlena Abdul Samad $\mathbb{1}$, ${ }^{1}$ Siti Khadijah Adam $\left(\mathbb{D},{ }^{2}\right.$ and Sharlina Mohamad $\left(\mathbb{D}{ }^{1}\right.$ \\ ${ }^{1}$ Integrative Medicine Cluster, Advanced Medical and Dental Institute, Universiti Sains Malaysia, SAINS@BERTAM, \\ 13200 Kepala Batas, Penang, Malaysia \\ ${ }^{2}$ Pharmacology Unit, Department of Human Anatomy, Faculty of Medicine and Health Sciences, Universiti Putra Malaysia, \\ 43400 UPM Serdang, Selangor, Malaysia \\ Correspondence should be addressed to Sharlina Mohamad; sharlina@usm.my
}

Received 8 September 2020; Revised 25 November 2020; Accepted 28 November 2020; Published 9 December 2020

Academic Editor: Dinesh Dhamecha

Copyright (c) 2020 Wan Ahmad Syazani Mohamed et al. This is an open access article distributed under the Creative Commons Attribution License, which permits unrestricted use, distribution, and reproduction in any medium, provided the original work is properly cited.

\begin{abstract}
Introduction. Propolis has been used traditionally in several countries for treating various diseases as it possessed healing properties including antioxidant and anticancer qualities. In Peninsular Malaysia, Tetrigona apicalis is one of the species of stingless bees mainly found in virgin jungle reserves which largely contribute to propolis production. Therefore, this study is designed to evaluate the phytochemical contents, antioxidant properties, and the cytotoxic effect of ethanolic crude of propolis extract against MCF7 and MCF 10A cell lines. Method. The ethanolic extract of propolis (EEP) was extracted using $80 \%$ ethanol. Identification of phytochemical contents and antioxidant properties of EEP was analysed by gas chromatography-mass spectrometry (GC-MS) and using 2, 2'-azinobis (3-ethylbenzothiazoline-6-sulphonic acid) (ABTS) method, respectively. The EEP cytotoxic activity was evaluated on MCF7 and MCF 10A using 3-(4, 5-dimethylthiazol-2-yl)-2, 5-diphenyltetrazolium bromide (MTT) assay. Results. Phytochemical contents of EEP demonstrated 28 compounds in which caryophyllene (99\%), $\beta$-amyrin (96\%), $\alpha$-amyrin (93\%), and caryophyllene oxide (93\%) were the main compounds. The percentage of ABTS ${ }^{+}$scavenging activity of EEP showed an inhibition of $9.5 \%$ with half-inhibitory concentration $\left(\mathrm{IC}_{50}\right)$ value of $1.68 \mathrm{mg} / \mathrm{mL}$. The EEP reduced MCF7 cells viability at IC I0 $_{50}$ value of $62.24 \mu \mathrm{g} / \mathrm{mL}, 44.15 \mu \mathrm{g} / \mathrm{mL}$, and $32.70 \mu \mathrm{g} / \mathrm{mL}$ at 24,48 , and 72 hours, respectively. The IC 50 value of MCF $10 \mathrm{~A}$ was $49.55 \mu \mathrm{g} / \mathrm{mL}, 56.05 \mu \mathrm{g} / \mathrm{mL}$, and $72.10 \mu \mathrm{g} / \mathrm{mL}$ at 24,48 , and 72 hours, respectively. The EEP cytotoxic effect of T. apicalis was more selective towards MCF7 at 72-hour incubation with a selectivity index (SI) of 2.20. Conclusion. The EEP has been shown to have antioxidants and potential bioactive compounds and inhibited proliferation of the MCF7 cells. Further studies on the EEP role in the apoptosis pathway and its screening towards other cell lines will be evaluated.
\end{abstract}

\section{Introduction}

Propolis is popularly known as one of the traditional herbal medicines used worldwide. Propolis is composed of a collection of sticky resinous materials from different plant sources that function as a sealant for hole or cracks in the beehive. The word propolis comes from the Greek word "pro" meaning barrier or in defence and "polis" meaning city, or in full "defence of the city (or the hive)" [1]. Propolis has been effectively used in folk medicine since ancient times to treat cold sores and abscesses. Fortified with its unique pharmacological properties, several studies such as antiinflammatory, antioxidant, antifungal, antibacterial, antihepatotoxic, and anticancer have been done and successfully published [1-3].

Research on propolis has become the topic of interest due to its bioactive compounds and vital biological activities, particularly in Southeast Asian countries [4]. In Malaysia, 
multiple researches have been conducted to observe the effectiveness of propolis for some biological activities. The detection of phytochemical compounds and antioxidant activity of Malaysian propolis was successfully discussed in several studies using gas chromatography-mass spectrometry (GC-MS) and thin-layer chromatography (TLC) [5-9].

The abundance of stingless bee species in Malaysia, 17 to 32 of them well-known [10], has led to many opportunities to research each type of propolis, based on its precise species. This study focuses on Tetrigona apicalis. Tetrigona apicalis first mentioned by Wallace and Smith [11] can be found mainly in the subtropical areas of Southeast Asia and IndoMalaya/Australasia [12]. T. apicalis was selected for this study, as this particular species can easily be found in virgin jungle reserves, especially in Peninsular Malaysia [13]. Unlike other main species of Malaysian stingless bees that are normally kept for meliponiculture, such as Heterotrigona itama and Geniotrigona thoracica [10], T. apicalis is native to the wild and known for its efficacy as a potent pollinator group in most ecosystems [14].

Rosli et al. [8], Gapar [15], and Asem et al. [16] have investigated the antioxidant activity of propolis extract from T. apicalis via 2, 2-diphenyl-1-picrylhydrazyl (DPPH) and 2, 2 '-azinobis (3-ethylbenzothiazoline-6-sulphonic acid) $\left(\mathrm{ABTS}^{+}\right.$) assay. Gapar [15] also correlated the antioxidant activity of T. apicalis propolis extract with total phenolic and flavonoid content.

The propolis extract of T. apicalis has also been well investigated in terms of its cytotoxic activities. Mat Nafi [9] found that T. apicalis did not exhibit any cytotoxic activity against HeLa (cervical cancer cells), MDA-MB-231 (breast cancer cells), and SK-UT-1 (uterine leiomyosarcoma cells) cancer cells. In addition, Gapar [15] also found that propolis extract of T. apicalis inhibited almost 50\% of HeLa cells through apoptosis induction.

To date, there exists no study on the cytotoxicity of T. apicalis on MCF 7 (breast cancer cells lines), a hormonedependent cell, and MCF 10A, nontumour human mammary epithelial cell lines. The in vitro cytotoxic assays for both cell types are crucial to determine whether the T. apicalis propolis extract is capable of working as a potential anticancer agent and in turn reducing toxicity towards noncancerous cells [17]. At the same time, studies specifically focused on the phytochemical screening of T. apicalis propolis extract for the identification of bioactive compounds for antioxidant and anticancer properties are lacking. Thus, this study aims to determine the phytochemical compounds of $T$. apicalis propolis extract along with $\mathrm{ABTS}^{+}$radical scavenging activity and cytotoxic effect against MCF7 and MCF 10A.

\section{Methodology}

2.1. Materials. Dulbecco's Modified Eagle Medium (DMEM), Roswell Park Memorial Institute (RPMI-1640), fetal bovine serum (FBS), trypsin/EDTA, penicillin-streptomycin, horse serum, hydrocortisone, Epidermal Growth Factor (EGF), insulin, phosphate buffer saline (PBS), and 3-(4, 5-dimethylthiazol-2-yl)-2, 5-diphenyltetrazolium bromide (MTT) were purchased from Gibco-BRL. ABTS ${ }^{+}$aqueous solution, potassium persulfate, ethanol, Trolox, methanol, and dimethyl sulfoxide (DMSO) were obtained from Sigma Aldrich (St. Louis, USA).

2.2. Sample Collection and Identification of T. apicalis. Propolis from the T. apicalis was collected at Tanjung Malim, Perak, Malaysia, by collecting the bee nest's inner part as described by Bonamigo et al. [18] with some modifications. The sample was kept in a plastic container and labelled. In order to identify the species of the stingless bees, the bee samples from the hive were taken as well. Alcohol swabs (soaked with 70\% isopropyl alcohol) with scanty drops of 5\% glacial acetic acid were prepared and placed in a killing jar prior to bee collection. The bee sample was put into the killing jar and the cover was closed tightly. The dead bees were put into the specimen container containing silica gel for further identification. Identification of the sample was completed by Centre for Insect Systematics (CIS), School of Environmental and Natural Resource Sciences, Faculty of Science and Technology of Universiti Kebangsaan Malaysia (UKM).

2.3. Preparation of Propolis Extract. Raw propolis samples with dust and the dead bees were removed physically from the samples. The preparations of the sample were in accordance with the method by Kothai and Jayanthi [19] with minor modifications. About $10 \mathrm{~g}$ powdered sample of T. apicalis propolis was extracted using $80 \%$ ethanol and stirred continuously at $400 \mathrm{rpm}$ for 24 hours. The suspensions of the samples were subjected to centrifugation at $3000 \mathrm{rpm}$ for 10 minutes. The extract was filtered using filter paper and concentrated using a rotary evaporator. The extracts were stored in a $-20^{\circ} \mathrm{C}$ freezer. Thereafter, the extract was freeze-dried and reduced to powder form.

2.4. Gas Chromatography-Mass Spectrometry (GC-MS). Agilent Technologies 6890N Network GC system was used for GC-MS evaluation of phytochemical contents of the T. apicalis propolis extract. Approximately, $1 \mathrm{mg}$ of the extract was dissolved in $1 \mathrm{~mL}$ methanol before filtering with a $0.45 \mu \mathrm{m}$ Whatman nylon syringe filter. The extract was injected automatically in a splitless mode. The starter temperature was placed at $70^{\circ} \mathrm{C}$ and kept for 2 minutes. The temperature was further increased to $160^{\circ} \mathrm{C}$ (with a rate of $10^{\circ} \mathrm{C} / \mathrm{min}$ ) and maintained for 5 minutes. Eventually, the temperature was escalated to $270^{\circ} \mathrm{C}$ (with a rate of $20^{\circ} \mathrm{C} / \mathrm{min}$ ) and stabilised for 8 minutes. The compounds were selected based on the comparison from the National Institute of Standards and Technology (NIST) library. The compounds that showed $80 \%$ similarity with chemical compounds from NIST were selected for this study.

2.5. $\mathrm{ABTS}^{+}$Radical Scavenging Assay. Determination of free radical scavenging activity in the ethanolic extract of propolis (EEP) was conducted by the method as described by Ismail et al. [6], Campos et al. [20], and Vongsak et al. [21] with minor modifications. Initially, $7 \mathrm{mM}$ aqueous solution 
of $\mathrm{ABTS}^{+}$and $2.45 \mathrm{mM}$ potassium persulfate in water was prepared and reacted. The mixture was kept in the dark at room temperature for 12 to 16 hours. $\mathrm{ABTS}^{+}$radical solution was diluted by reacting $1 \mathrm{~mL} \mathrm{ABTS}^{+}$radical with $50 \mathrm{~mL}$ ethanol to achieve the absorbance of $0.70( \pm 0.02)$ at $734 \mathrm{~nm}$ using a spectrophotometer (Biomate spectrophotometer, Thermo Fisher Scientific, USA).

Samples at concentrations ranging from 0.01 to $0.313 \mathrm{mg} / \mathrm{mL}$ were used. About $125 \mu \mathrm{L}$ of $\mathrm{ABTS}^{+}$radical was mixed with $1.25 \mu \mathrm{L}$ of samples in a 96-well plate. The mixture was then incubated in the dark for 6 minutes at $37^{\circ} \mathrm{C}$. All sample concentrations were tested in triplicates. The percentages of scavenging effects were measured by the equation as follows [22]:

$$
\text { Inhibition }(\%)=\frac{\left(A_{1}-A_{2}\right)}{A_{1}} \times 100 \% \text {, }
$$

where $A_{1}$ is the absorbance of control and $A_{2}$ is the absorbance of samples. Each concentration was done in triplicate, and the mean half-maximal inhibitory concentration $\left(\mathrm{IC}_{50}\right)$ value was counted as mean \pm standard deviation (SD). The positive control (Trolox) was treated under the same conditions as the samples.

\subsection{Cytotoxic Assay}

2.6.1. Cell Culture Maintenance. The MCF7 cell line was cultured in complete RPMI-1640 medium (included with penicillin-streptomycin and FBS); meanwhile, the MCF 10A cell line was cultured in complete DMEM (horse serum, hydrocortisone, EGF, insulin, and PBS). Both cells were incubated in a $5 \% \mathrm{CO}_{2}$ at $37^{\circ} \mathrm{C}$ for 48 to 72 hours until $80 \%$ confluency.

2.6.2. MTT Assay. MTT assay was used to determine the cytotoxic effect of the extract using the method described by Aziz et al. [23]. Both cell lines were seeded at a density of $1 \times 10^{4}$ cells $/ \mathrm{mL}$ in 96 -well plates. Both cells were incubated for 24 hours to allow for cell attachment and were treated with $100 \mu \mathrm{L}$ of extracts. The extracts were freshly prepared beforehand by diluting $100 \mathrm{mg}$ of EEP in $1 \mathrm{~mL}$ of $100 \%$ DMSO. An amount of less than $0.5 \%$ of DMSO was used in this step to prevent any toxic effect on the cell for any insoluble extracts [24]. Extracts with eight different concentrations ranging from 0.975 to $125 \mu \mathrm{g} / \mathrm{mL}$, positive and negative controls, were prepared with three replicates to ensure the validity of the results. Tamoxifen was used as a positive control, while negative control used media alone with $0.5 \%$ DMSO.

Cytotoxicity extracts were recorded for each time point (24, 48, and 72 hours). After incubation, $10 \mu \mathrm{L}$ of MTT solution was added to each well plate and was incubated for another 4 hours to produce formazan. Each well was added with $100 \mu \mathrm{L}$ DMSO. The purple colour formed due to the dissolved formazan with DMSO corresponded to the number of viable cells [9]. The absorbance was measured at $570 \mathrm{~nm}$ with a spectrophotometer. The results were calculated as the mean values and SD in triplicate. The measurement of cell viability along with the $\mathrm{IC}_{50}$ was calculated using the formula as stated as follows [25]:

$$
\text { cell viability }(\%)=\frac{[\text { average absorbance }(\text { sample }- \text { blank })]}{[\text { average absorbance }(\text { negative control }- \text { blank })]} \times 100 \text {. }
$$

2.7. Selectivity Index. The selectivity index (SI) was calculated in order to determine the cytotoxic selectivity of the tested substances by conducting the equation, as mentioned as follows:

$$
\mathrm{SI}=\frac{\mathrm{IC}_{50}^{\text {no cancer cells }}}{\mathrm{IC}_{50}^{\text {cancer cells }}}
$$

where SI $>2$ was considered as high selectivity as suggested by Rashidi et al. [26].

2.8. Statistical Analysis. The statistical analysis was done systematically in three replicates, and these data were represented as mean values along with SD. Microsoft Excel was used to plot graphs (cell viability (\%) versus concentration) in order to conclude the $\mathrm{IC}_{50}$ of the extract groups and positive control groups. A nonparametric (Kruskal Wallis) test was used to correlate the viability of the cell (\%) between the treatments with the negative control. All variables were evaluated via SPSS and Microsoft Excel with $p<0.05$ considered as significant.

\section{Results}

3.1. T. apicalis Propolis Extract. The percentage of yield of crude extract was measured with its physical appearance and recorded. The crude extract appeared whitish, and the samples were in powder form. The EEP sample from crude ethanolic extract yielded $57 \%$.

3.2. Gas Chromatography-Mass Spectrometry. The results of GC-MS analysis are summarised in Table 1.

3.3. ABTS $^{+}$Radical Scavenging Activity. Figure 1 shows the different concentrations $(0.01,0.02,0.039,0.078,0.156$, and $0.313 \mathrm{mg} / \mathrm{mL}$ ) of $\mathrm{ABTS}^{+}$and control in the form of a linear regression graph. The $\mathrm{IC}_{50}$ value was determined by using a linear regression equation [27]. $\mathrm{IC}_{50}$ is described as the total antioxidant necessary to decrease the initial $\mathrm{ABTS}^{+}$radical by half [28]. The $\mathrm{IC}_{50}$ of EEP and Trolox is further described in Table 2.

Based on Figure 1 and Table 2, the $\mathrm{IC}_{50}$ of EEP was $1.68 \mathrm{mg} / \mathrm{mL}$ with the maximal $\mathrm{ABTS}^{+}$radical scavenging 
TABLE 1: Phytochemical compounds identified in T. apicalis propolis extract using GC-MS.

\begin{tabular}{|c|c|c|c|c|c|}
\hline Peak & Compound & RT & MF & $\begin{array}{c}\text { MW } \\
(\mathrm{g} / \mathrm{mol})\end{array}$ & $\begin{array}{c}\text { Quality } \\
(\%)\end{array}$ \\
\hline 1 & Undecane & 5.602 & $\mathrm{C}_{11} \mathrm{H}_{24}$ & 156.18 & 95 \\
\hline 2 & Cyclohexane, 1-ethenyl-1-methyl-2-(1-methylethenyl)-4-(1-methylethylidene)- & 7.596 & $\mathrm{C}_{15} \mathrm{H}_{24}$ & 204.35 & 90 \\
\hline 3 & alpha-Cubebene & 7.68 & $\mathrm{C}_{15} \mathrm{H}_{24}$ & 204.35 & 89 \\
\hline 4 & Copaene & 7.895 & $\mathrm{C}_{15} \mathrm{H}_{24}$ & 204.35 & 98 \\
\hline 5 & $\begin{aligned} \text { Cyclohexane, 1-ethenyl-1-methyl-2, } & \text { 4-bis(1-methylethenyl)-, [1S-(1.alpha., 2.beta., } \\
& \text { 4.beta.)]- }\end{aligned}$ & 7.979 & $\mathrm{C}_{15} \mathrm{H}_{24}$ & 204.35 & 98 \\
\hline 6 & 3H-3a,7-Methanoazulene, 2, 4, 5, 6, 7, 8-hexahydro-1, 4, 9, 9-tetramethyl- & 8.111 & $\mathrm{C}_{15} \mathrm{H}_{24}$ & 204.35 & 93 \\
\hline 7 & 1H-Cycloprop[e]azulene, 1a, 2, 3, 4, 4a, 5, 6, 7b-octahydro-1, 1, 4, 7-tetramethyl- & 8.145 & $\mathrm{C}_{15} \mathrm{H}_{24}$ & 204.35 & 93 \\
\hline 8 & Caryophyllene & 8.229 & $\mathrm{C}_{15} \mathrm{H}_{24}$ & 204.35 & 99 \\
\hline 9 & alpha-Caryophyllene & 8.451 & $\mathrm{C}_{15} \mathrm{H}_{24}$ & 204.35 & 96 \\
\hline 10 & $\begin{array}{c}\text { Naphthalene, 1, 2, 3, 4, 4a, 5, } \\
\text { 6, 8a-octahydro-7-methyl-4-methylene-1-(1- } \\
\text { methylethyl)- }\end{array}$ & 8.562 & $\mathrm{C}_{15} \mathrm{H}_{24}$ & 204.35 & 98 \\
\hline 11 & 1, 6-Cyclodecadiene, 1-methyl-5-methylene-8-(1-methylethyl)- & 8.625 & $\mathrm{C}_{15} \mathrm{H}_{24}$ & 204.35 & 96 \\
\hline 12 & Bicyclogermacrene & 8.722 & $\mathrm{C}_{15} \mathrm{H}_{24}$ & 204.35 & 94 \\
\hline 13 & 1, 3-Benzodioxole, 4-methoxy-6-(2-propenyl)- & 8.806 & $\mathrm{C}_{11} \mathrm{H}_{12} \mathrm{O}_{3}$ & 192.21 & 95 \\
\hline 14 & Naphthalene, 1, 2, 3, 5, 6, 8a-hexahydro-4,7-dimethyl-1-(1-methylethyl)- & 8.84 & $\mathrm{C}_{15} \mathrm{H}_{24}$ & 204.35 & 98 \\
\hline 15 & Naphthalene, decahydro-4a-methyl-1-methylene-7-(1-methylethenyl)- & 9.09 & $\mathrm{C}_{15} \mathrm{H}_{24}$ & 204.35 & 98 \\
\hline 16 & Tricyclo[6.3.0.0(2, 4)] undec-8-ene, 3, 3, 7, 11-tetramethyl- & 9.188 & $\mathrm{C}_{15} \mathrm{H}_{24}$ & 204.35 & 87 \\
\hline 17 & 1H-Cycloprop[e]azulen-7-ol, decahydro-1, 1, 7-trimethyl-4-methylene- & 9.236 & $\mathrm{C}_{15} \mathrm{H}_{24} \mathrm{O}$ & 220.35 & 99 \\
\hline 18 & Caryophyllene oxide & 9.292 & $\mathrm{C}_{15} \mathrm{H}_{24} \mathrm{O}$ & 220.35 & 93 \\
\hline 19 & Cyclohexane, 1, 2-dimethyl-3, 5-bis(1-methylethenyl)- & 9.375 & $\mathrm{C}_{14} \mathrm{H}_{24}$ & 192.34 & 81 \\
\hline 20 & 12-Oxabicyclo[9.1.0] dodeca-3,7-diene, 1, 5, 5, 8-tetramethyl & 9.445 & $\mathrm{C}_{15} \mathrm{H}_{24} \mathrm{O}$ & 220.35 & 86 \\
\hline 21 & 1H-Cycloprop[e]azulene, decahydro-1,1,7-trimethyl-4-methylene- & 9.577 & $\mathrm{C}_{15} \mathrm{H}_{24} \mathrm{O}$ & 220.35 & 80 \\
\hline 22 & alpha-Cadinol & 9.667 & $15_{\mathrm{H}}$ & 222.37 & 93 \\
\hline 23 & Aristolene epoxide & 10.98 & $\mathrm{C}_{15} \mathrm{H}_{24} \mathrm{O}$ & 220.35 & 83 \\
\hline 24 & 1-Cyclohexene-1-butanal,.alpha.,2, 6, 6-tetramethyl- & 11.571 & $\mathrm{C}_{14} \mathrm{H}_{24} \mathrm{O}$ & 208.34 & 90 \\
\hline 25 & 1-Cyclohexene-1-butanal,.alpha.,2, 6, 6-tetramethyl- & 11.634 & $\mathrm{C}_{14} \mathrm{H}_{24} \mathrm{O}$ & 208.34 & 93 \\
\hline 26 & $\begin{array}{c}\text { 4, 4, 6a, 6b, 8a, 11, 11, 14b-Octamethyl-1, 4, 4a, 5, 6, 6a, 6b, 7, 8, 8a, 9, 10, 11, 12, 12a, 14, } \\
\text { 14a, 14b-octadecahydro-2H-picen-3-one }\end{array}$ & 25.003 & $\mathrm{C}_{30} \mathrm{H}_{48} \mathrm{O}$ & 424.7 & 93 \\
\hline 27 & beta-Amyrin & 25.621 & $\mathrm{C}_{30} \mathrm{H}_{50} \mathrm{O}$ & 426.7 & 96 \\
\hline 28 & alpha-Amyrin & 26.886 & $\mathrm{C}_{30} \mathrm{H}_{50} \mathrm{O}$ & 426.7 & 93 \\
\hline
\end{tabular}

Note: RT, retention time; MF, molecular formula; MW, molecular weight.

activity at $0.313 \mathrm{mg} / \mathrm{mL}$ and $9.5 \%$ inhibition corresponded to Trolox (49.8\%).

3.4. Cytotoxicity of EEP. Figures 2(a) and 2(b) show the different concentrations $(0.975,1.95,3.9,7.8,15.6,31.3,62.5$, and $125 \mu \mathrm{g} / \mathrm{mL}$ ) of EEP in MCF7 and MCF 10A, respectively. Figure 2(c) represents the different concentrations (0.156, $0.313,0.625,1.25,2.5,5,10$, and $20 \mu \mathrm{g} / \mathrm{mL}$ ) of tamoxifen.

Based on Figure 2, treatment of both MCF7 and MCF $10 \mathrm{~A}$ cells with different EEP concentrations resulted in a concentration-dependent effect. It can be observed that MCF7 cells that were treated with concentrations of 0.975 , $1.95,3.9,7.8$, and $15.6 \mu \mathrm{g} / \mathrm{mL}$ showed $100 \% \pm 0.02$ cell survivals, for three independent time points. At $31.3 \mu \mathrm{g} / \mathrm{mL}$ (with $98 \% \pm 2.75,84.2 \% \pm 2.22$, and $51.9 \% \pm 2.87$ for 24,48 , and 72 hours, resp.) and at $62.5 \mu \mathrm{g} / \mathrm{mL}$ (for 24 hours with $49.3 \% \pm 2.78)$, EEP started to inhibit proliferation of the cells and interrupted recovery. At higher concentrations $(125 \mu \mathrm{g} / \mathrm{mL}$ of 24 hours and 62.5 and $125 \mu \mathrm{g} / \mathrm{mL}$ of 48 hours and 72 hours), it shows that the EEP completely inhibited proliferation and prevented recovery.

For MCF 10A cells, different EEP concentrations (0.975, $1.95,3.9,7.8,15.6$, and $31.3 \mu \mathrm{g} / \mathrm{mL}$ ) showed $100 \% \pm 0.02$ cell survival for 24,48 , and 72 hours, respectively. At $62.5 \mu \mathrm{g} / \mathrm{mL}$, all three time points demonstrated a decline in cell proliferation (with $14.1 \% \pm 1.05,37.0 \% \pm 3.01$, and $58.6 \% \pm 1.35$ for 24,48 , and 72 hours, resp.). At $125 \mu \mathrm{g} / \mathrm{mL}$, cell proliferation was completely inhibited at 24 hours and showed a cell survival rate of $7.3 \% \pm 2.3$ (for 48 hours) and $2.9 \% \pm 0.58$ (for 72 hours).

In terms of tamoxifen, the concentration of $0.156 \mu \mathrm{g} / \mathrm{mL}$ showed a $100 \% \pm 0.02$ cell survival rate for 24,48 , and 72 hours, respectively. For 24 hours, the tamoxifen concentration of $0.313,0.625,1.252 .5,5$, and $10 \mu \mathrm{g} / \mathrm{mL}$ showed a gradual decline in cell proliferation (with $99.2 \% \pm 2.91$, $83.4 \% \pm 2.74,81.7 \% \pm 2.77,75.3 \% \pm 2.18,60.7 \% \pm 2.04$, and $46.3 \% \pm 3.61$, resp.). Meanwhile, for 48 and 72 hours, the cell survival rate of $100 \% \pm 0.02$ remained steady across several concentrations $(0.313,0.625,1.25,2.5$, and 5 (for 72 hours) $\mu \mathrm{g} / \mathrm{mL})$. For 48 hours, the cell proliferation took place at a concentration of $5 \mu \mathrm{g} / \mathrm{mL}(96.5 \% \pm 2.45)$ and gradually continued at $10 \mu \mathrm{g} / \mathrm{mL}(16.1 \% \pm 2.13)$. For 72 hours, the declining cell proliferation was shown at $10 \mu \mathrm{g} / \mathrm{mL}$ $(14.9 \% \pm 2.04)$. All three time points $(24,48$, and 72 hours) showed complete inhibition of cell proliferation at a concentration of $20 \mu \mathrm{g} / \mathrm{mL}$.

The $\mathrm{IC}_{50}$ of the EEP on the MCF7 showed a cytotoxic level of $62.24 \mu \mathrm{g} / \mathrm{mL} \pm 0.016, \quad 44.15 \mu \mathrm{g} / \mathrm{mL} \pm 0.02$, and $32.70 \mu \mathrm{g} / \mathrm{mL} \pm 0.034$ at 24,48 , and 72 hours, respectively, 


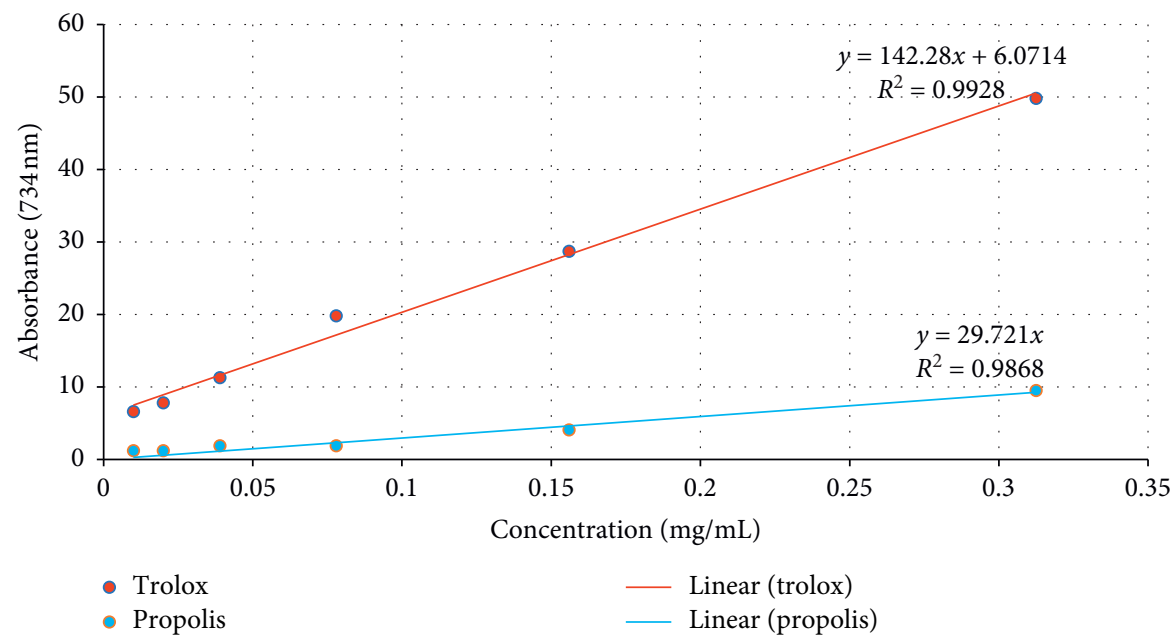

FIgure 1: Linear graph showing the regression line of EEP and Trolox for ABTS+.

TABLE 2: The linear regression equation and IC50 value of EEP and Trolox.

\begin{tabular}{lcc}
\hline Test solutions & Linear regression equation & $\mathrm{IC}_{50}$ value $(\mathrm{mg} / \mathrm{mL})$ \\
\hline EEP & $y=29.721 x$ & 1.68 \\
Trolox & $y=142.28 x+6.0714$ & 0.31 \\
\hline
\end{tabular}

whereas the $\mathrm{IC}_{50}$ of the EEP on the MCF $10 \mathrm{~A}$ showed a cytotoxic level of $49.55 \mu \mathrm{g} / \mathrm{mL} \pm 0.032,56.05 \mu \mathrm{g} / \mathrm{mL} \pm 0.026$, and $72.10 \mu \mathrm{g} / \mathrm{mL} \pm 0.027$ at 24,48 , and 72 hours, respectively. The SI of MCF 10A/MCF7 is $0.8,1.27$, and 2.20 for all three time points of 24,48 , and 72 hours of treatment, respectively. The summary of $\mathrm{IC}_{50}$ and SI is shown in Table 3.

\section{Discussion}

GC-MS analysis revealed 28 compounds from EEP derived from $T$. apicalis which were mainly predominant sesquiterpenes $\left(\mathrm{C}_{15} \mathrm{H}_{24}\right)$. Major compounds of sesquiterpenes can be divided into two elements, sesquiterpene hydrocarbons, such as $\beta$-caryophyllene (caryophyllene) (99\%), copaene (98\%), and cyclohexane, 1-ethenyl-1-methyl-2,4-bis(1-methylethenyl)-, [1S-(1.alpha, 2.beta, 4.beta.)] (98\%), and oxygenated sesquiterpenes, such as $1 \mathrm{H}$-cycloprop[e]azulen-7-ol, decahydro-1 ,1, 7-trimethyl-4-methylene (98\%) and $\beta$-caryophyllene oxide (caryophyllene oxide) (93\%). These elements were reported in the previous literature for their high anti-inflammatory [29, 30], antioxidant [31, 32], antimicrobial [32], and anticancer activities [33, 34]. For instance, $\beta$-caryophyllene and $\beta$-caryophyllene oxide that constitute one of the major compounds in T. apicalis propolis extract act as potent anticancer and antioxidants as suggested by Fidyt et al. [35]. Apart from that, EEP of T. apicalis interestingly was found to have a high quality of triterpenoids such as $\alpha$-amyrin (93\%) and $\beta$-amyrin (96\%) which were similar to the reports from Teixeira et al. [36]. Triterpenoids, typically $\alpha$-amyrin and $\beta$-amyrin, were mentioned in several studies regarding their potential for anticancer properties as described by Barros et al. [37] and Mirunalini et al. [38]. The chemical structure of sesquiterpene hydrocarbon ( $\beta$-caryophyllene), oxygenated sesquiterpenes ( $\beta$-caryophyllene oxide), and triterpenoids ( $\alpha$-amyrin and $\beta$-amyrin) are shown in Figure 3. To the best of our knowledge, this is the first time these compounds are detected in Malaysian propolis from the T. apicalis species which is significantly important as these compounds may be potentially high in antioxidant and anticancer properties, which will be explained later. However, further evaluation of these phytochemical compounds might be needed with the use of appropriate standards such as using high-performance liquid chromatography (HPLC), liquid chromatographymass spectrometry (LC-MS), and nuclear magnetic resonance (NMR) as it illustrates therapeutic significance.

GC-MS analysis in this study showed that the EEP of T. apicalis contains compounds with antioxidant and anticancer properties. Therefore, $\mathrm{ABTS}^{+}$radical scavenging assay was selected to analyse the antioxidant activity of EEP since $\mathrm{ABTS}^{+}$has a rapid kinetic reaction and intense response to antioxidants [42]. As suggested by Ibrahim et al. [5], the increment of antioxidant activity can be observed in the increase of radical scavenging activity that corresponded to a lesser value of $\mathrm{IC}_{50}$ of the extract. This is in agreement with our present study, where the EEP of T. apicalis possess inhibitory activity against $\mathrm{ABTS}^{+}$radical with $\mathrm{IC}_{50}$ of $1.68 \mathrm{mg} / \mathrm{mL}$ although positive control (Trolox) was better with $\mathrm{IC}_{50}$ of $0.31 \mathrm{mg} / \mathrm{mL}$. The graph in Figure 1 also showed that the radical scavenging activities were augmented, corresponding to the increase in the concentration of EEP. Previous studies by Rosli et al. [8] and Asem et al. [14] have also reported that $T$. apicalis propolis was very active in scavenging $\mathrm{ABTS}^{+}$and DPPH radicals. These suggest that EEP has the potential to combat oxidative stress which is strongly attributed to the existence of crucial antioxidant compounds detected by the GC-MS analysis.

The previous cytotoxicity study on EEP of T. apicalis by Mat Nafi et al. [9] reported that EEP did not exhibit cytotoxic activity against different cancer cell lines. MDAMB-231, SK-UT-1, and HeLa for 72 hours with $\mathrm{IC}_{50}$ of HeLa were $68 \mu \mathrm{g} / \mathrm{mL}$. Since EEP of T. apicalis consists of many bioactive compounds, a lower $\mathrm{IC}_{50}$ was predicted [23]. At 24 hours, EEP showed $\mathrm{IC}_{50}$ of $62.24 \mu \mathrm{g} / \mathrm{mL} \pm 0.016$ 


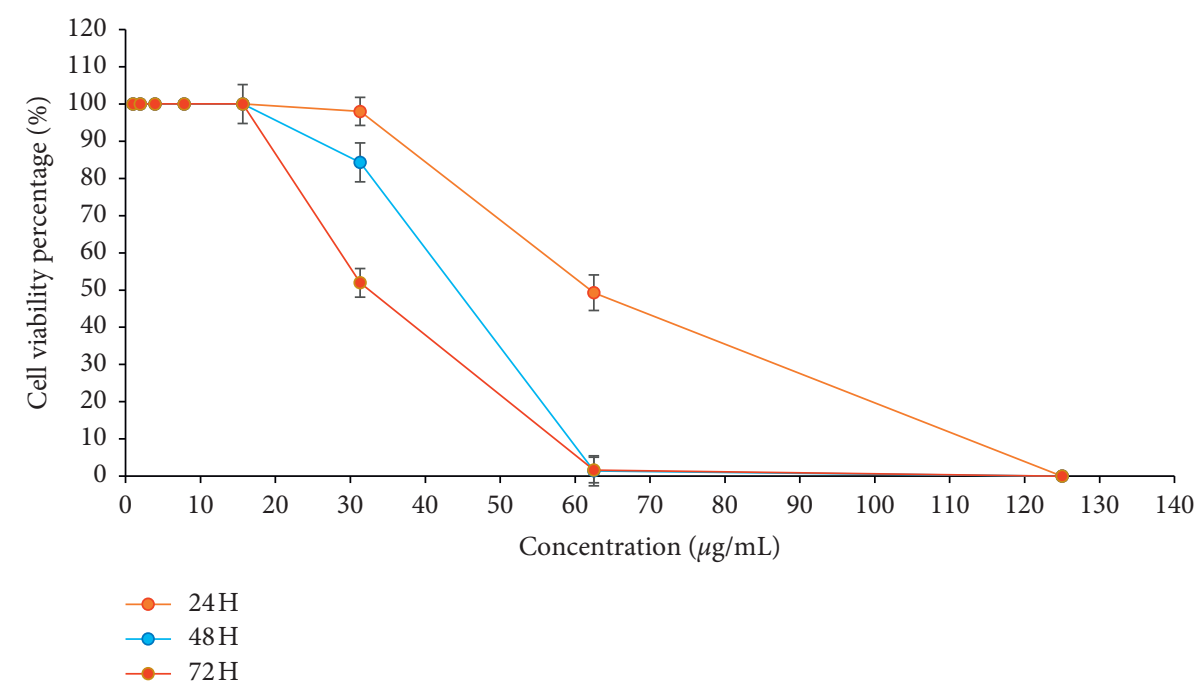

(a)

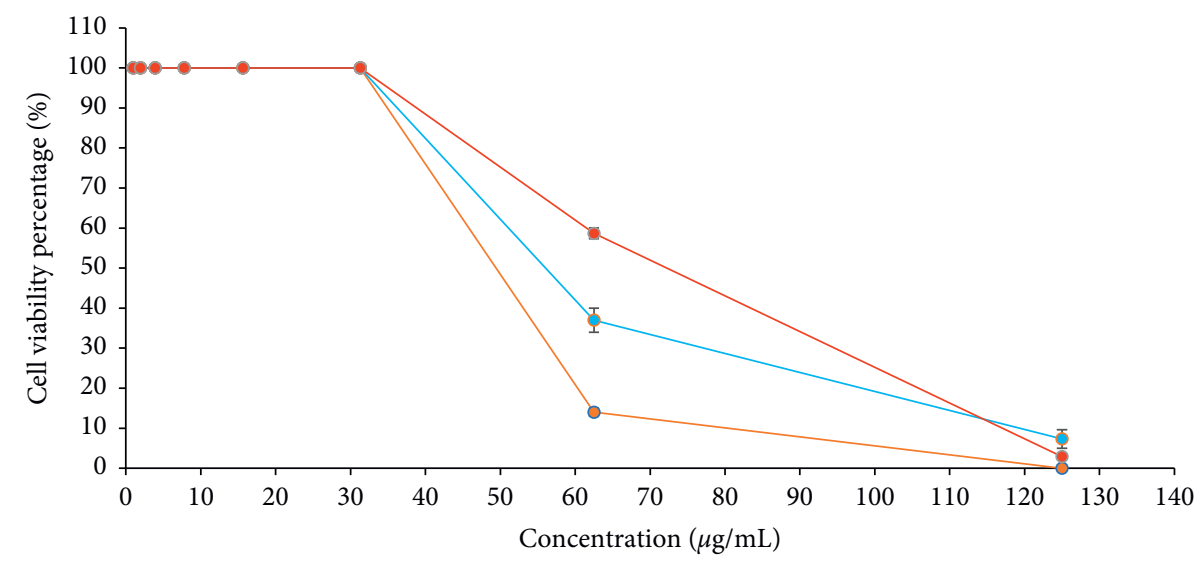

$$
\begin{aligned}
& -24 \mathrm{H} \\
& --48 \mathrm{H} \\
& --72 \mathrm{H}
\end{aligned}
$$

(b)

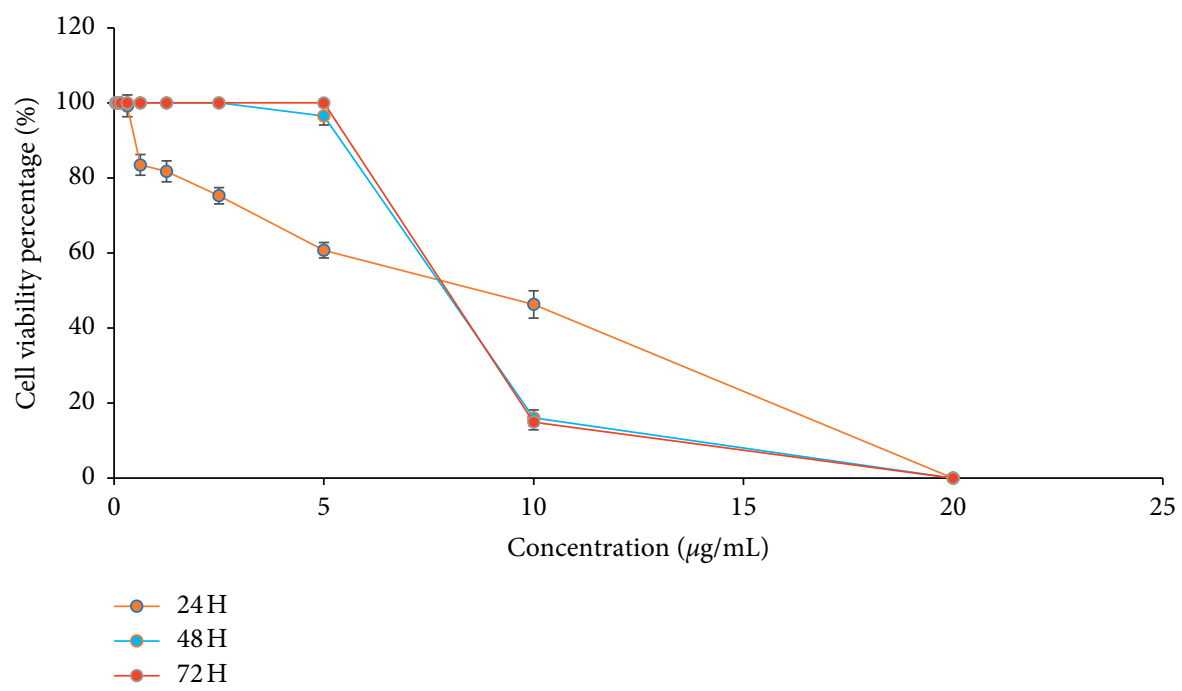

(c)

FIGURE 2: Graphs showing cell survival rates of (a) MCF7 cells and (b) MCF 10A cells with EEP. The cell survival rates with tamoxifen are shown in (c). Data presented as mean $\pm \mathrm{SD} ;{ }^{*} p<0.05$ is considered a significant value. 
TABLE 3: $\mathrm{IC}_{50}$ and SI at three time points $(24,48$, and 72 hours) for MCF7, MCF 10A, and tamoxifen.

\begin{tabular}{lccc}
\hline Incubation time (hours) & MCF7 & MCF 10A & Tamoxifen \\
\hline 24 & $62.24 \mu \mathrm{g} / \mathrm{mL} \pm 0.016$ & $49.55 \mu \mathrm{g} / \mathrm{mL} \pm 0.032$ & $9.05 \mu \mathrm{g} / \mathrm{mL} \pm 0.035$ \\
48 & $44.15 \mu \mathrm{g} / \mathrm{mL} \pm 0.02$ & $56.05 \mu \mathrm{g} / \mathrm{mL} \pm 0.026$ & $7.85 \mu \mathrm{g} / \mathrm{mL} \pm 0.02$ \\
72 & $32.70 \mu \mathrm{g} / \mathrm{mL} \pm 0.034$ & $72.10 \mu \mathrm{g} / \mathrm{mL} \pm 0.027$ & $7.85 \mu \mathrm{g} / \mathrm{mL} \pm 0.02$ \\
\hline
\end{tabular}

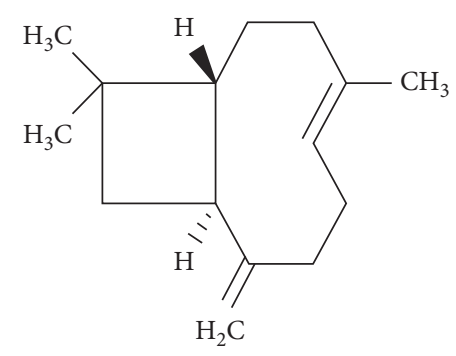

(a)
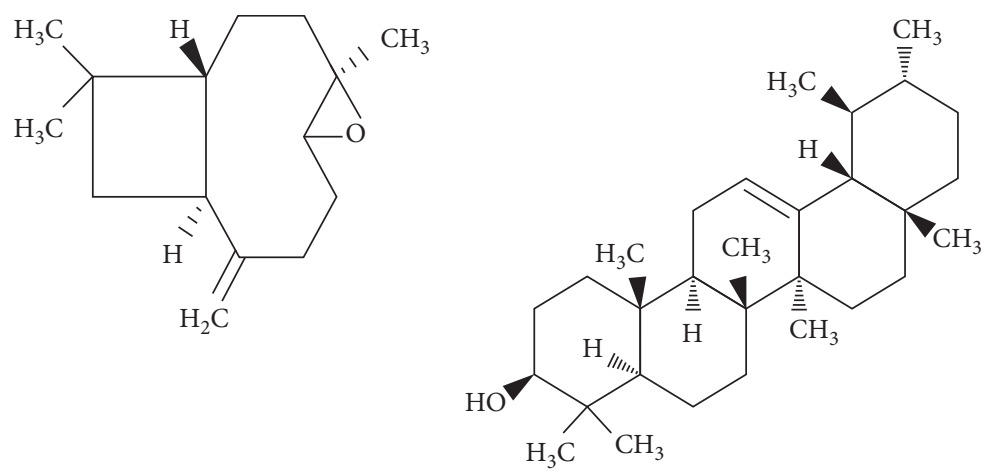

(c)<smiles>C[C@@H]1[C@H]([C@@]2(C)CCC3[C@H]4CCC(C)(C)CC4=CC[C@]32C)CC[C@@H](O)C1(C)C</smiles>

(d)

FiguRE 3: Chemical structure of sesquiterpene hydrocarbon, (a) $\beta$-caryophyllene [39], oxygenated sesquiterpenes, (b) $\beta$-caryophyllene oxide [40], and triterpenoids, (c) $\alpha$-amyrin and (d) $\beta$-amyrin [41].

and $49.55 \mu \mathrm{g} / \mathrm{mL} \pm 0.032$ in MCF7 and MCF $10 \mathrm{~A}$ cells, respectively. The $\mathrm{IC}_{50}$ was subsequently reduced at 48 and 72 hours in MCF7, whereas it was gradually increased in MCF 10A. The United States National Cancer Institute (USNCI) stated that crude extract with $\mathrm{IC}_{50}$ estimations less than $30 \mu \mathrm{g} / \mathrm{mL}$ is a promising agent for the development of an anticancer medication, as mentioned by Quintans et al. [43]. Therefore, cytotoxicity of EEP in MCF7 at 72 hours had the most promising result for its potential as an anticancer agent since it has a low level of IC $_{50}(32.70 \mu \mathrm{g} / \mathrm{mL} \pm 0.034)$. The target estimation of lesser IC $_{50}(<30 \mu \mathrm{g} / \mathrm{mL})$ might be achieved if the time point exceeded 72 hours. These results indirectly reflect the relevance of EEP as a potential treatment in MCF7, also known to be ER, PR-positive, and HER2-negative breast cancer cell lines that are effective for hormonal treatment [44]. Based on the comparison with NIST, $\beta$-caryophyllene may play a role in inducing apoptosis in cancer cells with the catalytic activity involving DNA ladder and caspase-3. It has been known that $\beta$-caryophyllene augments the cytotoxicity of the isomers isocaryophyllene and $\alpha$-humulene, particularly in MCF7 cancer cell lines $[45,46]$.

MCF $10 \mathrm{~A}$ is originally nontumorigenic and thus SI was determined to find the best way to evaluate the selectiveness of treatment towards normal cell lines or cancer cell lines. As mentioned by Rashidi et al. [26], high selectivity against cancer cells was concluded where SI $>2$, whereas if SI values fall in between 0 and 2, the treatment toxicity was otherwise not selective towards any cells. Based on our study, the SI at three time incubation points $(24,48$, and 72 hours) was 0.8 , 1.27 , and 2.20, respectively. Therefore, it can be deduced that EEP showed general toxicity at $24-48$ hours because the value is below 2.0 while it displayed selectivity when incubated further till 72 hours. As a result, EEP can be a potential candidate for a cytotoxic agent at 72 hours as evidenced by SI of 2.20. As MCF7 and MCF 10A were presented for the first time for the cytotoxic study of T. apicalis, both exhibited similar effectiveness of cytotoxic action which are time-dependent. The concentration-dependent EEP also plays a role in determining the 
effectiveness of EEP as discussed earlier. Therefore, these two key points are essential in determining the best potential of EEP to act as a cytotoxic agent towards MCF7.

\section{Conclusion}

EEP has been shown to have a high antioxidant level and potential bioactive compounds and can inhibit the proliferation of the MCF7 cells. The highest cytotoxic activities which corresponded to the lowest $\mathrm{IC}_{50}$ of MCF7 was obtained at 72 hours of EEP treatment with the best SI at the same time point. Further studies are recommended to determine the role of EEP in the apoptosis pathway and the effect of this extract on other cell lines.

\section{Data Availability}

The analysed data used to support the findings of this study are included within the article.

\section{Additional Points}

Key Points. This journal article provides the effectiveness of Tetrigona apicalis propolis extract in promoting cytotoxic effect towards breast cancer cell line (MCF7) and nontumour human mammary epithelial cell lines (MCF 10A). The propolis extract of $T$. apicalis exhibited significant antioxidant properties and potential bioactive compounds and was capable of inhibiting the proliferation of the MCF7 cells. The highest cytotoxic activity of MCF7 was acquired at 72 hours of EEP treatment with the best SI at the same time point.

\section{Conflicts of Interest}

The authors hereby declare that they have no conflicts of interest.

\section{Acknowledgments}

This work was supported by a Universiti Sains Malaysia short-term grant, 1001/CIPPT/6315160.

\section{References}

[1] E. L. Ghisalberti, "Propolis: a review," Bee World, vol. 60, no. 2, pp. 59-84, 1979.

[2] A. H. Banskota, Y. Tezuka, and S. Kadota, "Recent progress in pharmacological research of propolis," Phytotherapy Research, vol. 15, no. 7, pp. 561-571, 2001.

[3] F. R. G. Silva, T. M. S. Matias, L. I. O. Souza et al., "Phytochemical screening and in vitro antibacterial, antifungal, antioxidant and antitumor activities of the red propolis Alagoas," Brazilian Journal of Biology, vol. 79, no. 3, pp. 452-459, 2019.

[4] B. Trusheva, D. Trunkova, and V. Bankova, "Different extraction methods of biologically active components from propolis: a preliminary study," Chemistry Central Journal, vol. 1, p. 13, 2007.

[5] N. Ibrahim, N. F. S. Mohd Niza, M. M. Mohd Rodi, A. J. Zakaria, Z. Ismail, and K. S. Mohd, "Chemical and biological analyses of Malaysian stingless bee propolis extracts,"
Malaysian Journal of Analytical Science, vol. 20, no. 2, pp. 413-422, 2016.

[6] N. Z. Ismail, H. Arsad, M. R. Samian, and M. R. Hamdan, "Determination of phenolic and flavonoid contents, antioxidant activities and GC-MS analysis of Clinacanthus nutans (Acanthaceae) in different locations," Agrivita Journal of Agricultural Science, vol. 39, no. 3, pp. 335-344, 2017.

[7] A. A. M. Badiazaman, N. B. Zin, A. R. Annisava, N. Elani, M. Nafi, and K. S. Mohd, "Phytochemical screening and antioxidant properties of stingless bee Geniotrigona thoracica propolis," Malaysian Journal of Fundamental and Applied Sciences, vol. 15, no. 2-1, pp. 330-335, 2019.

[8] N. L. Rosli, H. Roslan, E. A. Omar et al., "Phytochemical analysis and antioxidant activities of Trigona apicalis propolis extract," AIP Conference Proceedings, vol. 1791, no. 1, Article ID 020018, 2016.

[9] N. E. Mat Nafi, N. B. Md Zin, N. Pauzi et al., "Cytotoxicity, antioxidant and phytochemical screening of propolis extracts from four different Malaysian stingless bee species," Malaysian Journal of Fundamental and Applied Sciences, vol. 15, no. 2-1, pp. 307-312, 2019.

[10] N. Kelly, M. S. N. Farisya, T. Kumara, and P. Marcela, "Species diversity and external nest characteristics of stingless bees in meliponiculture," Tropical Agricultural Science, vol. 37, no. 3, pp. 293-298, 2014.

[11] F. Smith, "Catalogue of the hymenopterous insects collected at Sarawak, Borneo; Mount Ophir, Malacca; and at Singapore, by A. R. Wallace," Zoological Journal of the Linnean Society, vol. 2, no. 6, pp. 42-88, 1857.

[12] C. Rasmussen, "Catalog of the Indo-Malayan/Australasian stingless bees (Hymenoptera: Apidae: Meliponini)," Zootaxa, vol. 1935, no. 1, pp. 1-80, 2008.

[13] H. M. W. Salim, A. D. Dzulkiply, R. D. Harrison, C. Fletcher, A. R. Kassim, and M. D. Potts, "Stingless bee (Hymenoptera: Apidae: Meliponini) diversity in dipterocarp forest reserves in Peninsular Malaysia," The Raffles Bulletin of Zoology, vol. 60, no. 1, pp. 213-219, 2012.

[14] F. Jauker, B. Bondarenko, H. C. Becker, and I. Steffan-dewenter, "Pollination efficiency of wild bees and hoverflies provided to oilseed rape," Agricultural and Forest Entomology, vol. 14, no. 1, pp. 81-87, 2012.

[15] N. A. A. Gapar, "Phytochemical analysis and potential anticancer activity of propolis extract derived from Malaysian Trigona apicalis in human cervical cells," vol. 3, pp. 40-41, Masters thesis, Universiti Sains Malaysia, George Town, Malaysia, 2018.

[16] N. Asem, N. A. A. Gapar, N. A. H. Hapit, and E. A. Omar, "Correlation between total phenolic and flavonoid contents with antioxidant activity of Malaysian stingless bee propolis extract," Journal of Apicultural Research, vol. 59, no. 4, pp. 1-6, 2019.

[17] Y. Frión-herrera, A. Díaz-garcía, H. Rodríguez-sánchez, J. L. Ruiz-fuentes, L. M. Fidalgo, and W. N. Setzer, "Cytotoxic effect of Cuban propolis extracts on normal cells and in-vitro basal toxicity assay to estimate acute oral toxicity," American Journal of Essential Oils and Natural Products, vol. 2, no. 1, pp. 19-23, 2014.

[18] T. Bonamigo, J. F. Campos, A. S. Oliveira et al., "Antioxidant and cytotoxic activity of propolis of Plebeia droryana and Apis mellifera (Hymenoptera, Apidae) from the Brazilian Cerrado biome," PLoS One, vol. 12, no. 9, Article ID e0183983, 2017.

[19] S. Kothai and B. Jayanthi, "Evaluation of antioxidant and antimicrobial activity of stingless bee propolis (Tetragonula iridipennis) of Tamilnadu, India," International Journal of 
Pharmacy and Pharmaceutical Sciences, vol. 6, no. 8, pp. 8185, 2014.

[20] J. F. Campos, U. P. d. Santos, P. d. S. d. Rocha et al., "Antimicrobial, antioxidant, anti-inflammatory, and cytotoxic activities of propolis from the stingless bee Tetragonisca fiebrigi (Jataí)," Evidence-based Complementary and Alternative Medicine, vol. 2015, Article ID 296186, 11 pages, 2015.

[21] B. Vongsak, S. Kongkiatpaiboon, S. Jaisamut, S. Machana, and C. Pattarapanich, "In vitro alpha glucosidase inhibition and free-radical scavenging activity of propolis from Thai stingless bees in Mangosteen orchard," Revista Brasileira de Farmacognosia, vol. 25, no. 5, pp. 445-450, 2015.

[22] I. A. Adebayo, H. A. Gagman, W. G. Balogun et al., "Detarium microcarpum, Guiera senegalensis, and Cassia siamea induce apoptosis and cell cycle arrest and inhibit metastasis on MCF7 breast cancer cells," Evidence-based Complementary and Alternative Medicine, vol. 2019, Article ID 6104574, 12 pages, 2019.

[23] A. Aziz, M. Zukiflee, A. Bakar, F. Zuraina, and M. Yusof, "Concentration and time dependent cytotoxic effect of methanolic crude extracts of Pseuduvaria macrophylla on the human cancer cell line," in Proceedings of International Congress on Science \& Technology, Bali, Indonesia, December 2017.

[24] J. L. Hanslick, K. Lau, K. K. Noguchi et al., "Dimethyl sulfoxide (DMSO) produces widespread apoptosis in the developing central nervous system," Neurobiology of Disease, vol. 34, no. 1, pp. 1-10, 2009.

[25] M. M. Sidek, N. Z. Ismail, N. N. M. Zain et al., "Cytotoxicity activity of Christia vespertilionis leaves extracts against HeLa cells and the detection of compounds by GC-MS," Journal of Biological \& Scientific Opinion, vol. 7, no. 6, pp. 1-8, 2019.

[26] M. Rashidi, A. Seghatoleslam, M. Namavari et al., "Selective cytotoxicity and apoptosis-induction of Cyrtopodion scabrum extract against digestive cancer cell lines," International Journal of Cancer Management, vol. 10, no. 5, pp. 1-7, 2017.

[27] M. T. Oo, M. Min, K. Myo, and M. Tun, "Preliminary phytochemical screening and antioxidant activity of Brassica oleracea Linn. (broccoli)," 3rd Myanmar Korea Conference Research Journal, vol. 3, no. 4, pp. 1564-1569, 2015.

[28] A. Maimulyanti and A. R. Prihadi, "Chemical composition , phytochemical and antioxidant activity from extract of Etlingera elatior flower from Indonesia," Journal of Pharmacognosy and Phytochemistry, vol. 3, no. 6, pp. 233-238, 2015.

[29] H. Makabe, N. Maru, A. Kuwabara, T. Kamo, and M. Hirota, "Anti-inflammatory sesquiterpenes fromCurcuma zedoaria," Natural Product Research, vol. 20, no. 7, pp. 680-685, 2006.

[30] E. S. á R. D. C. Da Silveira, L. N. Andrade, and D. P. De Sousa, "Sesquiterpenes from essential oils and anti-inflammatory activity," Natural Product Communications, vol. 10, no. 10, pp. 1767-1774, 2015.

[31] A. L. Khan, H. Khan, J. Hussain et al., "Sesquiterpenes: the potent antioxidants," Pakistan Journal of Scientific and Industrial Research, vol. 51, pp. 343-350, 2008.

[32] S. Dahham, Y. Tabana, M. Iqbal et al., "The anticancer, antioxidant and antimicrobial properties of the sesquiterpene $\beta$-caryophyllene from the essential oil of Aquilaria crassna," Molecules, vol. 20, no. 7, pp. 11808-11829, 2015.

[33] D. A. Zaleta-pinet, I. P. Holland, M. Muñoz-ochoa et al., "Cytotoxic compounds from Laurencia pacifica," Organic and Medicinal Chemistry Letters, vol. 4, no. 1, p. 8, 2014.
[34] S. Jain, J. Dwivedi, P. K. Jain, S. Satpathy, and A. Patra, "Medicinal plants for treatment of cancer: a brief review," Pharmacognosy Journal, vol. 8, no. 2, pp. 87-102, 2016.

[35] K. Fidyt, A. Fiedorowicz, L. Strzadała, and A. Szumny, " $\beta$-caryophyllene and $\beta$-caryophyllene oxide-natural compounds of anticancer and analgesic properties," Cancer Medicine, vol. 5, no. 10, pp. 3007-3017, 2016.

[36] É. W. Teixeira, D. Message, G. Negri, A. Salatino, and P. C. Stringheta, "Seasonal variation, chemical composition and antioxidant activity of Brazilian propolis samples," Evidence-based Complementary and Alternative Medicine, vol. 7, no. 3, pp. 307-315, 2010.

[37] F. W. A. Barros, P. N. Bandeira, D. J. B. Lima et al., "Amyrin esters induce cell death by apoptosis in HL-60 leukemia cells," Bioorganic \& Medicinal Chemistry, vol. 19, no. 3, pp. 12681276, 2011.

[38] S. Mirunalini, S. Isabella, and V. Vaithiyanathan, "Antiproliferative effect of alpha amyrin on Hep2 cells by inducing cytotoxicity and oxidant antioxidant status modifications," FoodSci: Indian Journal of Research in Food Science and Nutrition, vol. 3, no. 2, pp. 44-47, 2016.

[39] H. Javed, S. Azimullah, M. E. Haque, S. K. Ojha, and M. G. Perrone, "Cannabinoid type 2 (CB 2) receptors activation protects against oxidative stress and neuroinflammation associated dopaminergic neurodegeneration in rotenone model of Parkinson's Disease," Frontiers in Neuroscience, vol. 10, no. 8, pp. 1-14, 2016.

[40] J. D. Fátima, G. Dias, O. G. Miguel, and M. D. Miguel, "Composition of essential oil and allelopathic activity of aromatic water of Aster lanceolatus willd:(Asteraceae)," Brazilian Journal of Pharmaceutical Science, vol. 45, no. 3, pp. 469-474, 2009.

[41] G. M. Andrade, C. M. Helena, and F. A. Santos, "Anti-inflammatory effect of $\alpha, \beta$-Amyrin, a pentacyclic triterpene from Protium heptaphyllum in rat model of acute periodontitis," Inflammopharmacology, vol. 15, pp. 1-5, 2007.

[42] K. J. Lee, Y. C. Oh, W. K. Cho, and J. Y. Ma, "Antioxidant and anti-inflammatory activity determination of one hundred kinds of pure chemical compounds using offline and online screening HPLC assay," Evidence-based Complementary and Alternative Medicine, vol. 2015, Article ID 165457, 13 pages, 2015.

[43] J. Quintans, B. Soares, R. Ferraz et al., "Chemical constituents and anticancer effects of the essential oil from leaves of Xylopia laevigata," Planta Medica, vol. 79, no. 2, pp. 123-130, 2013.

[44] A. S. Levenson and V. C. Jordan, "MCF-7: the first hormoneresponsive breast cancer cell line," Cancer Research, vol. 57, no. 15, pp. 3071-3078, 1997.

[45] J. Legault and A. Pichette, "Potentiating effect of $\beta$-caryophyllene on anticancer activity of $\alpha$-humulene, isocaryophyllene and paclitaxel," Journal of Pharmacy and Pharmacology, vol. 59, no. 12, pp. 1643-1647, 2007.

[46] F. Francomano, A. Caruso, A. Barbarossa et al., " $\beta$-caryophyllene: a sesquiterpene with countless biological properties," Applied Sciences, vol. 9, no. 5420, pp. 1-19, 2019. 